\title{
INVESTIGACIÓN
}

\section{Physical properties of mutton tallow}

\author{
By G. R. List ${ }^{\star}$, K. R. Steidley, W. E. Neff and G. D. Snowder ${ }^{1}$
}

\author{
Food and Industrial Oil Research, National Center for Agricultural Utilization, ARS, USDA ${ }^{2}$ \\ 1815 N. University Street, Peoria, II 61604 \\ E-mail: Listgr@ncaur.usda.gov
}

\begin{abstract}
${ }^{1}$ U. S. Sheep Experiment Station, ARS, USDA, DuBois, ID, 83423
${ }^{2}$ Names are necessary to report factually an available data: the USDA neither guarantees nor warrants the standard of the product, and the use of the name USDA implies no approval of the product to the exclusion of others that may also be suitable.
\end{abstract}

\section{RESUMEN}

\section{Propiedades físicas de sebo de cordero.}

Se han determinado las propiedades físicas de sebo de cordero aislado de riñones, lomo e intestino mediante resonancia magnética nuclear de pulso y técnicas de punto de deslizamiento. La grasa de riñón mostró los mayores contenidos de grasa sólida medida en un rango de temperatura de $10-50^{\circ} \mathrm{C}$ seguido por la grasa del intestino y siendo la grasa del lomo la que tuvo el contenido más bajo de grasa sólida. El sebo de cordero contiene ácidos grasos saturados en proporción del $52-64 \%$, índice de yodo que oscilan entre 34-44 y cantidades pequeñas de ácidos grasos trans $(3-4 \%)$

PALABRAS-CLAVE: Ácidos grasos saturados - Grasa sólida - Indice de yodo - Punto de fusión - Resonancia magnética nuclear de pulso - Sebo de cordero.

\section{SUMMARY}

\section{Physical properties of mutton tallow.}

The physical properties of mutton tallows isolated from the kidney, back and intestinal regions were determined by pulsed nuclear magnetic resonance and Mettler dropping point techniques. Kidney fat showed the highest amounts of solid fat measured over a temperature range of $10-50{ }^{\circ} \mathrm{C}$ followed by intestinal fat and back fat showed the least amount of solid fat. Mutton tallows contain $52-64 \%$ saturated acids, have iodine values ranging from $34-44$ and contain small amounts (3-4\%) of trans fatty acids.

KEY-WORDS: lodine value - Melting point - Mutton tallow - Pulsed nuclear magnetic resonance - Saturated fatty acidSolid fat.

\section{INTRODUCTION}

Although the fatty acid composition and physical properties of mutton tallow are dispersed throughout the literature (Grompone 1990; Boskish 1993), little information is available on the physical properties of fat isolated from various portions of the carcass. We wish to report some compositional and physical properties of tallows isolated from the kidney, intestinal and back areas of the sheep carcass.

\section{EXPERIMENTAL}

Samples from the kidney, back and intestinal areas were taken from a $170 \mathrm{lb}$ ewe who had succumbed during lambing. The samples were frozen in dry ice and shipped to the Northern Laboratory. The fat was isolated by the following procedures. Kidney, back and intestinal fat $(10 \mathrm{~g}$ each) were cut into small pieces and homogenized with $50 \mathrm{ml}$ chloroform for 5 minutes on ice, followed by homogenization with $100 \mathrm{ml}$ methanol 30 seconds and a final homogenization (30 seconds) with $50 \mathrm{ml}$ chloroform. The extracts were allowed to stand for 30 minutes on ice, after which the mixture was filtered through filter paper under vacuum. The filtrate was then rinsed 3 times with chloroform. The combined filtrate was stripped of solute on a rotating evaporator and the residue was treated with $50 \mathrm{ml}$ acetonitrile, the solvent removed. This procedure was repeated. The fat was dissolved in $25 \mathrm{ml}$ hexane and passed through Sep-Pak filters. After removal of the solvent, the sample was treated again with $25 \mathrm{ml}$ acetonitrile. After removal of the solvent, $25.1 \mathrm{~g}$ $(83 \%)$ of purified fat was isolated for further analysis. Thin layer chromatography showed that only triglycerides were present.

Fatty acid composition was determined by gas-liquid chromatography as methyl esters as described previously (Christie 1973). Solid fat content (SFC) and Mettler dropping point determinations were by conducted according to official AOCS methods (Firestone 1989). Dilation 
data were taken from the solid fat index (SFI) Dilatometric method AOCS method. Lipase hydrolysis was conducted as reported previously (Neff, et al. 1992). Triglyceride structures were calculated from the lipase data according to Coleman (1961) and Van Der Waal (1960).

\section{RESULTS AND DISCUSSION}

The physical properties and fatty acid composition of mutton tallow isolated from various areas of the sheep carcass are shown in Table I. A study published in 1990 (Grampone) showed that tallows produced in Uruguay contain higher levels of oleic acid and lower levels of palmitic and stearic acid than those produced in other countries. Tallows from Uruguay contained about $40 \%$ oleic acid and about $45 \%$ palmitic and stearic acid. Results given in Table
II are in accord with this study. The composite prepared from equal amounts of kidney, back and intestinal areas contain $54 \%$ saturated acids and $37 \%$ oleic acid. The melting point of Uruguayan tallow is reported to be $45.2^{\circ} \mathrm{C}$ compared to $46.3^{\circ} \mathrm{C}$ found in the present study. Solid fat content data given in Table 1 show that kidney fat contains more solid fat at temperatures from $10-50^{\circ} \mathrm{C}$ while intestinal fat is intermediate and back fat has the least. The solid fat content profiles suggest that mutton tallows would perform well as baking shortenings. The major triglycerides of mutton tallows as determined from lipase hydrolysis data are shown in Table II. About $90 \%$ of the triglycerides found in mutton tallows are accounted for by 9 triglycerides formed from oleic, palmitic and stearic acids whose melting points range from $5^{\circ} \mathrm{C}$ to $73^{\circ} \mathrm{C}$.

Table I

Fatty acid composition and pshysical properties of mutton tallow

\begin{tabular}{|c|c|c|c|c|c|c|c|c|c|c|c|c|c|c|c|c|c|}
\hline \multirow[b]{2}{*}{ Fat } & \multicolumn{7}{|c|}{ Fatty Acids } & \multirow{2}{*}{$\begin{array}{l}\text { lodine } \\
\text { Value }\end{array}$} & \multirow{2}{*}{$\begin{array}{c}\% \text { Trans } \\
\text { Acids }\end{array}$} & \multirow{2}{*}{$\begin{array}{c}\text { Drop } \\
\text { Melting } \\
\text { Point }\left({ }^{\circ} \mathrm{C}\right)\end{array}$} & \multicolumn{7}{|c|}{ Solid Fat Content $\% \operatorname{Temp}\left({ }^{\circ} \mathrm{C}\right)$} \\
\hline & $14: 0$ & $16: 0$ & $16: 1$ & $18: 0$ & $18: 1$ & $18: 2$ & $18: 3$ & & & & 10 & 21,1 & 26,7 & 33,3 & 40 & 45 & 50 \\
\hline Kidney & 2,2 & 20,3 & 0,9 & 41,7 & 31,4 & 2,4 & 1 & 33,8 & 4,5 & 51,1 & 65,6 & 44,5 & 40,4 & 35,1 & 23,6 & 13,9 & 4,9 \\
\hline Back & 2,7 & 24,6 & 1,0 & 24,3 & 44,8 & 1,6 & 1,0 & 43,9 & 2,7 & 43,1 & 34,0 & 17,7 & 45 & 10 & 4,4 & 0 & 0 \\
\hline Intestinal & 2,8 & 23,6 & 1,0 & 33,9 & 35,4 & 2,3 & 1,2 & 37,5 & 4,1 & 48,4 & 56,7 & 35,9 & 31,9 & 26,2 & 15,4 & 6,5 & 0,8 \\
\hline Composite & 2,6 & 22,1 & 2,5 & 32,1 & 37,3 & 2,3 & 1,0 & 38,6 & 6,0 & 46,3 & 50,5 & 29,9 & 26,2 & 21,2 & 11,0 & 4,4 & 0,1 \\
\hline
\end{tabular}

a Equal weight of kidney, back, intestinal fats.

Table II

Major triglycerides of sheep tallows ${ }^{a}$

\begin{tabular}{ccccc} 
& \multicolumn{5}{c}{ Fat } & \\
\cline { 2 - 4 } Triglyceride (\%) & Kidney & Back & Intestinal & Melting Point $\left({ }^{\mathbf{o}} \mathbf{C}\right)^{\mathbf{b}}$ \\
\hline OOO & 3,0 & 8,4 & 4,3 & 5,0 \\
POO & 5,6 & 16 & 8,4 & 19 \\
OPO & 1,1 & 1,3 & 1,5 & 22,5 \\
SOO & 11,7 & 15,4 & 12,9 & 37,5 \\
OSO & 2,0 & 1,5 & 1,7 & 38,0 \\
POP & 2,4 & 7,5 & 4,2 & \\
OPP & 2,0 & 2,5 & 2,8 & 43,5 \\
SOP & 14,0 & 17,1 & 15,9 & \\
SPO & 4,3 & 2,8 & 4,3 & 63,5 \\
SOS & 11,4 & 7,1 & 9,5 & 73 \\
SSO & 7,6 & 2,7 & 5,1 & \\
PPS & 5,4 & 3,6 & 5,8 & \\
PSS & 11 & 3,7 & 8,1 & \\
SSS & 7,4 & 1,2 & 3,8 & \\
Total (\%) & 88,9 & 90,8 & 88,3 & \\
UUU & & & & \\
UUS & 3,9 & 9,7 & 5,5 & \\
USS & 21,2 & 35,1 & 25,6 & \\
USU & 18,2 & 10,7 & 16,4 & \\
SUS & 3,4 & 2,9 & 3,6 & \\
SSS & 28,7 & 31,9 & 29,9 & \\
\hline
\end{tabular}

a By lipase hydrolysis, triglycerides over $1 \%$ listed.

b From literature. 


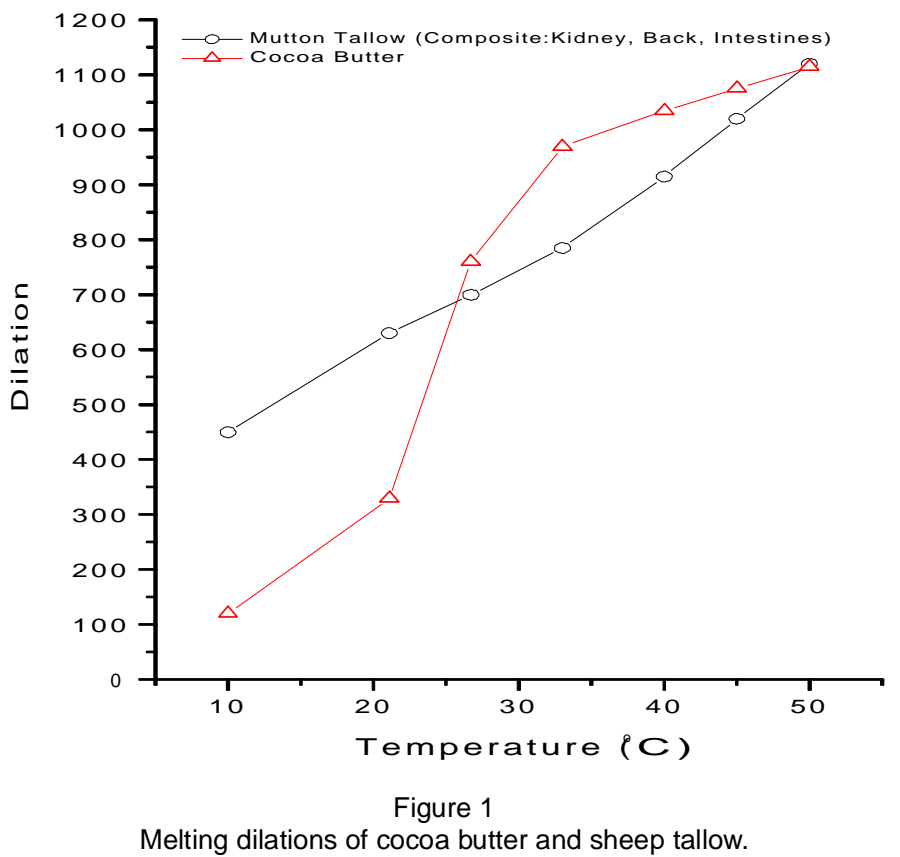

Because of a basic difference in their structures, nearly all vegetable fats and oils have saturated acids distributed nearly exclusively at the 1 and 3 positions of the glycerol moiety giving rise to symmetrical triglycerides when esterified with unsaturated acids. On the other hand, animal fats are composed of triglycerides where saturated acids are found in the 2 position. As a result, non-symmetrical triglycerides are present.

Although the fatty acid composition of mutton tallow is very similar to cocoa butter, the two fats exhibit very different melting profiles. Cocoa butter is composed of symmetrical triglycerides of the SUS type (where $\mathrm{U}=$ oleic and $\mathrm{S}=$ palmitic or stearic). Typically, cocoa butter is composed of about $80 \%$ POS, SOS and POP (Shukla 1995). Mutton tallow, however, contains a number of both symmetrical and non-symmetrical disaturated triglycerides.

The melting dilations of cocoa butter and sheep tallow are shown in Figure 1, where the melting point dilations are plotted against temperatures ranging from 10 to $50^{\circ} \mathrm{C}$. Cocoa butter exhibits a sharp inflection in melting dilation at temperatures between 20 and $30^{\circ} \mathrm{C}$ which is indicative of its sharply melting properties. Cocoa butter shows a melting point of $29.3^{\circ} \mathrm{C}$. On the other hand, mutton tallow shows nearly a linear relationship between melting dilation and temperature indicative of a slowly melting fat. The difference between the two curves can be attributed to basic differences in their triglyceride structures. Cocoa butter, which is comprised of symmetrical triglycerides, melts very sharply compared to sheep tallow, which contains a mixture of both symmetrical and non-symmetrical triglycerides.

\section{REFERENCES}

Bockish, M. (1993). Fats and Oils Handbook. AOCS Press, Champaign II. 153-155.

Christie, W. W. (1973) Lipid Analysis, first edition. Pergamon Press, New York. 85-102.

Coleman, M. H. (1961). Further studies on the pancreatic hydrolysis of some natural fats. J. Amer. Oil Chem Soc. 38,685-688.

Grompone, M. A. (1990). Characteristics of Uruguayan mutton tallow. J. Amer. Oil Chem Soc. 67, 980.

Neff, W. F. , Zeitoun, M. A. M. and Weisleder.D. (1992). Resolution of lipase lipolysis mixtures from soybean oil by a solid phase extraction procedure. J. Chromatog, 589, 353-357.

Official and Tentative Methods of the American Oil Chemists' Society, $4^{\text {th }}$ edition. (1989). D. Firestone. (ed) AOCS, Champaign, IL,. Solid fat index Cd10-57, Dropping point Cc18-86, Solid fat content Cd16-81.

Shukla, V. K. S. (1995). Confectionary fats in developments in oils and fats. R. J. Hamilton (ed) Blackie Academic and Professional, Chapman and Hall, London. 66-94.

VanDerWal, R. J. (1960). Calculation of the distribution of the saturated and unsaturated acyl groups in fats from pancreatic lipase hydrolysis data. J. Amer. Oil Chem Soc. $37,18-20$. 